Article

\title{
Evaluation of the Skin Sensitization Potential of Carbon Nanotubes Using Alternative In Vitro and In Vivo Assays
}

\author{
Sung-Hyun Kim * (D), Dong Han Lee, Jin Hee Lee, Jun-Young Yang, Hyo-Sook Shin, JeongPyo Lee, \\ Kikyung Jung, Jayoung Jeong, Jae-Ho Oh and Jong Kwon Lee * \\ Division of Toxicological Research, National Institute of Food and Drug Safety Evaluation, Ministry of Food and \\ Drug Safety, Osong, Cheongju 28159, Chungcheongbuk-do, Korea; donghan04@korea.kr (D.H.L.); \\ tod98@korea.kr (J.H.L.); yangjy@korea.kr (J.-Y.Y.); aqua978@korea.kr (H.-S.S.); origene@korea.kr (J.L.); \\ kikyung@korea.kr (K.J.); 0jjy@korea.kr (J.J.); chopin68@korea.kr (J.-H.O.) \\ * Correspondence: tjdgus32@korea.kr (S.-H.K.); jkleest@korea.kr (J.K.L.);
} Tel.: +82-43-719-5110 (S.-H.K.); +82-43-719-4351 (J.K.L.)

Received: 2 November 2020; Accepted: 10 December 2020; Published: 16 December 2020

\begin{abstract}
Carbon nanotubes (CNTs) are one of the major types of nanomaterials that have various industrial and biomedical applications. However, there is a risk of accidental exposure to CNTs in individuals involved in their large-scale production and in individuals who use products containing CNTs. This study aimed to evaluate the skin sensitization induced by CNTs using two alternative tests. We selected single-wall carbon nanotubes and multi-walled carbon nanotubes for this study. First, the physiochemical properties of the CNTs were measured, including the morphology, size, and zeta potential, under various conditions. Thereafter, we assessed the sensitization potential of the CNTs using the ARE-Nrf2 Luciferase KeratinoSens ${ }^{\mathrm{TM}}$ assay, an in vitro alternative test method. In addition, the CNTs were evaluated for their skin sensitization potential using the LLNA: BrdU-FCM in vivo alternative test method. In this study, we report for the first time the sensitization results of CNTs using the KeratinoSens ${ }^{\mathrm{TM}}$ and LLNA: BrdU-FCM test methods in this study. This study found that both CNTs do not induce skin sensitization. These results suggest that the KeratinoSens ${ }^{\mathrm{TM}}$ and LLNA: BrdU-FCM assay may be useful as alternative assays for evaluating the potential of some nanomaterials that can induce skin sensitization.
\end{abstract}

Keywords: skin sensitization; alternative to animal testing; KeratinoSens ${ }^{\mathrm{TM}}$; LLNA; nanomaterial; CNT

\section{Introduction}

Carbon nanotubes (CNTs) are a major type of nanomaterial that is used for various industrial and biomedical applications [1,2]. In recent years, with the growing number and production volume of CNTs, concerns about their toxicity have also increased exponentially. Generally, nanomaterials are defined as particles less than $100 \mathrm{~nm}$ in at least one dimension [3], which exhibit various physicochemical properties associated with a nanostructure [4].

The various physicochemical characteristics of a nanomaterial are the major determinants of its toxic potential [5,6]. In normal environmental conditions, nanomaterials are mostly poorly soluble; however, some nanomaterials have shown to be soluble in lysosomal fluid or gastric fluid $[7,8]$. Dissolution of nanomaterials can cause toxicity due to the release of ions [9].

The major exposure pathways of nanomaterials are inhalation, ingestion, and absorption into the skin. Absorption pathways within the skin can cause lesions, such as local inflammation, contact allergy, and skin sensitization $[10,11]$. Recently, with an exponential increase in the cosmetic commercialization 
of nanomaterials and the safety concerns associated with them, the safety evaluation of nanomaterials has gained importance [12]. In addition, in recent cosmetic tests, the importance of alternative test methods is increasing due to concern about animal welfare and the 3R principles [13,14]. However, as these guidelines are based on chemical substances, it is necessary to develop alternative test methods that reflect the properties of nanomaterials.

The current knowledge on the chemical and biological mechanisms associated with skin sensitization has been summarized in the form of an adverse outcome pathway, starting with the molecular initiating event through intermediate events to the adverse effect, namely allergic contact dermatitis [15]. The skin sensitization test, adverse outcome pathway (AOP), is largely classified into an animal test and nonanimal test method. Nonanimal test methods include the direct peptide reactivity assay (DPRA, key event 1) to confirm peptide reactivity, the ARE-Nrf2 Luciferase Test (KeratinoSens ${ }^{\mathrm{TM}}$, key event 2), and the human Cell Line Activation Test (h-CLAT, key event 3) assay to evaluate the sensitization of test substances using cell lines. Key event 4 (LLNA: DA, BrdU-ELISA, and FCM) is an animal test method to evaluate the activation of mice lymph nodes to sensitizers [16-19].

According to a recent report, sensitization evaluation using several nanomaterials was performed, and the applicability of these assays for testing the nanomaterials was evaluated [20,21]. However, there is still a lack of information on the skin sensitization results of nanomaterials. Therefore, this study was performed to evaluate the skin sensitization potential of two types of CNTs using the ARE-Nrf2 Luciferase KeratinoSens ${ }^{\mathrm{TM}}$ and LLNA: BrdU-FCM assays.

\section{Materials and Methods}

\subsection{Carbon Nanotubes}

Single-wall carbon nanotubes (SWCNTs, product No. 704121) and multi-walled carbon nanotubes (MWCNTs, product No. 698849) were purchased from Sigma-Aldrich (St Louis, MO, USA). Their morphology was observed by transmission electron microscopy (TEM) (JEM-1200EX II, JEOL, Tokyo, Japan) and the average diameter was calculated by measuring both CNTs using the ImageJ software program ver.1.48. The zeta potential of the CNTs was measured using a Zetasizer-Nano ZS instrument (Malvern Instruments, Malvern, UK) in different working solutions: Dulbecco's modified Eagle's medium (DMEM; GIBCO, Grand Island, NY, USA) containing 1\% heat-inactivated fetal bovine serum (FBS; GIBCO) and N,N-dimethylformamide (DMF; Sigma-Aldrich, CASRN. 68-12-2) solution containing 3\% heat-inactivated mouse serum. The levels of endotoxin were evaluated using an Endpoint Chromogenic Limulus Amoebocyte Lysate assay (Cambrex, Walkersville, MD, USA).

\subsection{Preparation of CNT Suspensions}

The suspensions of CNTs in media were prepared by slightly modifying a previously described method [22,23]. Briefly, the CNT stock solutions were dispersed in distilled water (DW) and sonicated at $40 \mathrm{kHz}$ with a $100 \mathrm{~W}$ output power for $30 \mathrm{~min}$ in a bath-type sonicator (Saehan-Sonic, Seoul, Korea). Thereafter, DMEM supplemented with 1\% FBS was added to different working concentrations. As CNTs cannot be converted into molar concentration, as determined in the test guideline 442D, the test concentration was set based on the mass dose $(\mu \mathrm{g} / \mathrm{mL})$. In addition, the test concentration was set through two preliminary tests to confirm the EC50 concentration of CNTs. In LLNA: BrdU-FCM assay, CNT stock solution was dispersed in DW and sonicated at $40 \mathrm{kHz}$ with a $100 \mathrm{~W}$ output power for $30 \mathrm{~min}$ in a bath-type sonicator (Saehan-Sonic). Thereafter, a 3\% serum equivalent of the final volume was added to the initial dispersion and further dispersed for $30 \mathrm{~min}$. Finally, DMF solution was added to prepare a working solution $(25,50$, and $100 \%)$.

\subsection{Cell Culture}

A transgenic keratinocyte cell line, with a stable insertion of the Luciferase reporter gene under control of the ARE-element KeratinoSens ${ }^{\mathrm{TM}}$ cells, was provided from Givaudan Suisse SA (Vernier, 
Switzerland). KeratinoSens ${ }^{\mathrm{TM}}$ cells were cultured in DMEM media supplemented with $10 \%$ FBS and $0.5 \mathrm{mg} / \mathrm{mL}$ Geneticin (G418; Sigma-Aldrich, St. Louis, MO, USA). The cells were sub-cultured every 3-4 days at $80-90 \%$ confluence for a maximum of 25 passages. For the assay, KeratinoSens ${ }^{\mathrm{TM}}$ cells were seeded into a 96-well culture plate at a density of $1 \times 10^{4}$ cells/well. Then, the culture media were replaced with fresh medium (DMEM supplemented with $1 \%$ FBS) and incubated in a humidified atmosphere condition of $5 \% \mathrm{CO}_{2}$ at $37^{\circ} \mathrm{C}$.

\subsection{CNT Treatments and KeratinoSens ${ }^{\mathrm{TM}}$ Assay Methods}

KeratinoSens $^{\mathrm{TM}}$ cells were seeded into 96-well plates at a density of $1 \times 10^{4}$ cells/well and incubated overnight to reach approximately $80 \%$ confluency. The cells were washed once with pre-warmed DPBS (Gibco), followed by the addition of fresh medium containing single-wall carbon nanotubes (SWCNTs) and multi-walled carbon nanotubes (MWCNTs) $(0.05-1000 \mu \mathrm{g} / \mathrm{mL}$ ), and the plates were then incubated for $48 \mathrm{~h}$. Positive control (cinnamic aldehyde, 4-64 $\mu \mathrm{M}$ ) was tested in parallel. The viability of the treated cells was measured using the thiazolyl blue tetrazolium bromide (3-(4,5-dimethylthiazo-2-yl)-2,5-diphenyl-tetrazolium bromide) assay reduction test (Promega, Madison, WI, USA). To exclude colorimetric interference from CNTs present in the cells, the supernatant was transferred into clear $96-w e l l$ plates and the absorbance was measured at $570 \mathrm{~nm}$ with a microplate reader (Tecan, Männedorf, Switzerland). The cell viability (\%) was calculated based on the optical density of the vehicle control and blank. Luciferase activity was measured using the One-Glo ${ }^{\mathrm{TM}}$ Luciferase assay kit (Promega). The luminescence intensity of each sample was measured using a luminometer (Promega) and multi-microplate reader (Synergy 2, BioTek, Winooski, VT, USA). Luciferase induction was calculated based on the luminescence values of the vehicle control and blank.

\subsection{Animals}

Female BALB/C mice (7 weeks old, Specific Pathogen Free) were purchased from ORIENT BIO Inc. (Seongnam, Korea). Animals were kept at an animal facility in the Korea Ministry of Food and Drug Safety (MFDS) and acclimated for at least six days before experiments. Mice were housed in a relative humidity of $3-\mathrm{C} 70 \%$ at $22 \pm 3{ }^{\circ} \mathrm{C}$. This experiment was approved by the Institutional Animal Care and Use Committee (IACUC) of MFDS (Approval number: MFDS-20-013c2; date: 23 April 2020).

\subsection{CNTs Treatments and LLNA: BrdU-FCM Assay Methods}

On days 1, 2, and 3, dispersed CNT suspension, vehicle, and positive control (25\% hexyl cinnamic aldehyde in AOO) were applied to the dorsal skin of each ear of the mouse at the same time-point. The CNT suspensions were prepared fresh daily before application. On day 5, the mice were intraperitoneally injected with $100 \mu \mathrm{L}$ of BrdU solution $(20 \mathrm{mg} / \mathrm{mL})$. On day 6 , the mice were sacrificed, and their auricular lymph nodes were excised. Then, excised lymph nodes were mashed with a spatula to prepare lymph node cells (LNCs). Isolated LNCs were counted using a hemocytometer after staining with trypan-blue solution. The counted LNCs $\left(1.5 \times 10^{6}\right.$ cells $\left./ \mathrm{mL}\right)$ were prepared, according to the protocol provided in the manufacturer's kit. The viable LNCs were counted and a total of 10,000 gated cells were analyzed using BD FACS Calibur ${ }^{\mathrm{TM}}$ flow cytometry (BD Biosciences, San Jose, CA, USA), as previously described [24,25]. Stimulation index (SI) values were calculated using the formula, as described in the OECD TG 442B guideline. If the SI value was 2.7 or above, the test materials were classified as sensitizers.

\section{Results}

\subsection{Physicochemical Characteristic of CNTs}

Figure 1 shows the TEM images of SWCNTs and MWCNTs used in this study. The results confirmed that both SWCNTs and MWCNTs had a size of less than $100 \mathrm{~nm}$ in one dimension. The characteristics of CNTs are summarized in Table 1. Measurement of the zeta potential showed 
that all CNTs were negatively charged, with charge in distilled water (DW) and working solution. The results of the Limulus Amoebocyte Lysate test showed that both SWCNTs and MWCNTs had endotoxin levels that were lower than the limit of detection $(0.1 \mathrm{U} / \mathrm{mL})$.
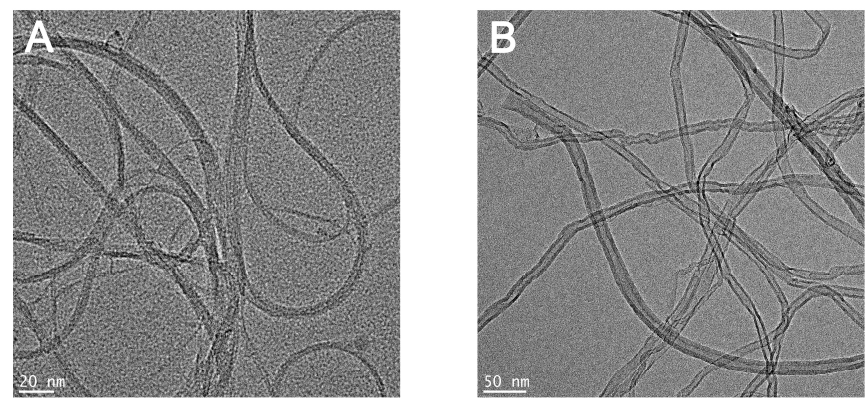

Figure 1. Transmission electron microscopy images of the (A) single-wall carbon nanotubes (SWCNTs) (bar $=20 \mathrm{~nm}$ ) and $($ B $)$ multi-walled carbon nanotubes (MWCNTs) $($ bar $=50 \mathrm{~nm})$ in distilled water.

Table 1. Characteristics of SWCNTs and MWCNTs.

\begin{tabular}{ccccc}
\hline \multirow{2}{*}{ Characteristic } & \multicolumn{2}{c}{ KeratinoSens $^{\text {TM }}$} & \multicolumn{2}{c}{ LLNA: BrdU-FCM } \\
\cline { 2 - 5 } & SWCNT & MWCNT & SWCNT & MWCNT \\
\hline Average diameter $(\mathrm{nm})$ & $5.97 \pm 1.48$ & $12.30 \pm 2.18$ & $5.97 \pm 1.48$ & $12.30 \pm 2.18$ \\
Average length $(\mu \mathrm{m})$ & 1 & 10 & 1 & 10 \\
Surface area $\left(\mathrm{m}^{2} / \mathrm{g}\right)$ & $\geq 700$ & 216 & $\geq 700$ & 216 \\
\hline Zeta potential $(\mathrm{mV})$ & & & \\
in DW & $-27.40 \pm 1.59$ & $-34.99 \pm 0.80$ & $-27.40 \pm 1.59$ & $-33.99 \pm 0.80$ \\
in working solution * & $-29.23 \pm 1.79$ & $-26.99 \pm 3.07$ & $-18.80 \pm 0.93$ & $-38.38 \pm 1.41$ \\
\hline CNT purity $(\%)$ & $\geq 77$ & 99 & $\geq 77$ & 99 \\
Carbon purity $(\%)$ & $\geq 90$ & $\geq 98$ & $\geq 90$ & $\geq 98$ \\
\hline Endotoxin $(\mathrm{EU} / \mathrm{mL})$ & \multicolumn{5}{c}{$<0.1$} \\
\hline
\end{tabular}

* The working solution was prepared with DW stock (1\%) + DMEM, containing 1\% FBS in KeratinoSens ${ }^{\mathrm{TM}}$ assay. The working solution in LLNA: BrdU-FCM assay was prepared using DW stock $(10 \%)+$ DMF, containing $3 \%$ mouse serum. Data are expressed as mean $\pm \mathrm{SD}, n=6$. SWCNTs $=$ single-wall carbon nanotubes, MWCNTs $=$ multi-walled carbon nanotubes, $\mathrm{DW}=$ distilled water, EU = endotoxin, DMEM = Dulbecco's modified Eagle's medium, FBS = fetal bovine serum, $\mathrm{DMF}=\mathrm{N}, \mathrm{N}$-dimethylformamide.

\subsection{Evaluation of CNTs in the KeratinoSens ${ }^{\mathrm{TM}}$ Assay}

SWCNTs and MWCNTs were assessed for their skin sensitization potential using the KeratinoSens $^{\mathrm{TM}}$ assay (Table 2 and Figure 2). All CNTs did not induce the activity of the luciferase reporter in contrast to the positive control (Figures 2 and 3). The $\mathrm{EC}_{1.5}$ value for both CNTs was $>1000 \mu \mathrm{g} / \mathrm{mL}$, thus classifying it as a nonsensitizer. Cytotoxicity, $\mathrm{IC}_{50}$ values were found to be $234.98 \mu \mathrm{g} / \mathrm{mL}$ for MWCNTs and $185.90 \mu \mathrm{g} / \mathrm{mL}$ for SWCNTs.

Table 2. SWCNTs and MWCNTs evaluated in KeratinoSens ${ }^{\mathrm{TM}}$ assay.

\begin{tabular}{|c|c|c|c|c|c|c|c|}
\hline \multirow[b]{2}{*}{ Nanomaterials } & \multirow[b]{2}{*}{ CAS RN } & \multirow[b]{2}{*}{$\begin{array}{c}\text { Physical } \\
\text { Form }\end{array}$} & \multicolumn{5}{|c|}{ KeratinoSens ${ }^{\mathrm{TM}}$ Assay Results } \\
\hline & & & $\operatorname{Imax}$ & $\begin{array}{c}\mathrm{EC}_{1.5} \\
(\mu \mathrm{g} / \mathrm{mL})\end{array}$ & $\begin{array}{c}\text { Cell Viability } \\
(\%)^{a}\end{array}$ & $\begin{array}{c}\mathrm{IC}_{50} \\
(\mu \mathrm{g} / \mathrm{mL})\end{array}$ & Classification \\
\hline SWCNT & $308068-56-6$ & Solid & 1.07 & $>1000$ & $>70$ & 185.90 & Negative \\
\hline MWCNT & $308068-56-6$ & Solid & 1.39 & $>1000$ & $>70$ & 234.98 & Negative \\
\hline
\end{tabular}

${ }^{\mathrm{a}}$ Cell viability (\%) at $\mathrm{EC}_{1.5}$. 
A

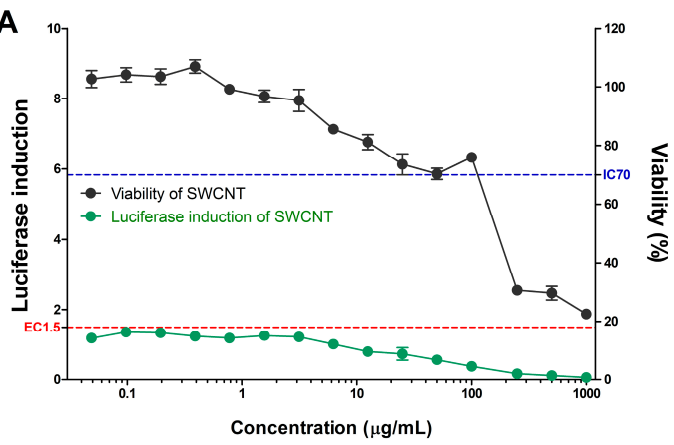

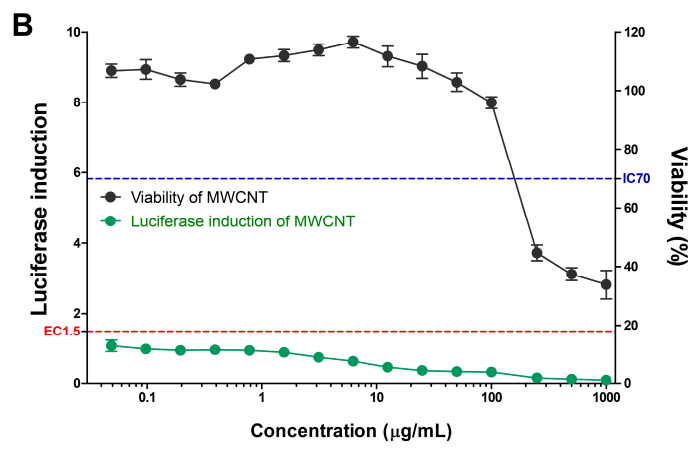

Figure 2. The induction of luciferase activity (green line) and cell viability (black line) in the KeratinoSens ${ }^{\mathrm{TM}}$ assay. KeratinoSens ${ }^{\mathrm{TM}}$ cells were treated with the (A) SWCNTs and (B) MWCNTs. Data are expressed as mean \pm standard deviation values $(n=6)$.

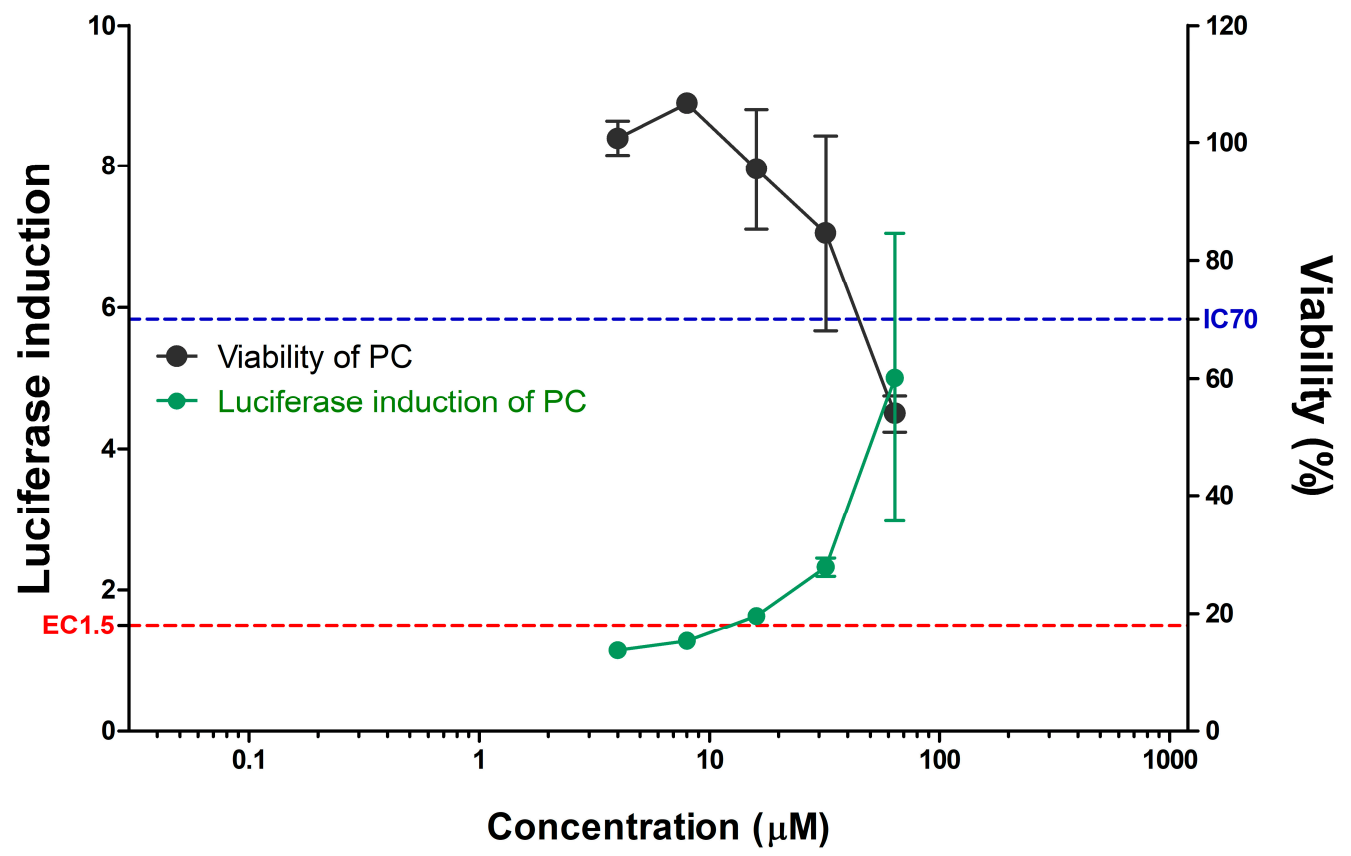

Figure 3. Luciferase activity (green line) and cell viability (black line) of positive control (cinnamic aldehyde, CASRN. 14371-10-9) in KeratinoSens ${ }^{\mathrm{TM}}$ assay. Data are expressed as mean \pm standard deviation values $(n=6)$. Positive control $(4-64 \mu \mathrm{M})$ was tested in parallel.

\subsection{Evaluation of CNTs in the LLNA: BrdU-FCM Assay}

SWCNTs and MWCNTs were assessed for their skin sensitization potential using the LLNA: BrdU-FCM assay (Figures 4 and 5). Except for the positive control, no significant results were found at any concentration in the CNTs. The SI values of SWCNTs and MWCNTs were less than 2.7, as calculated by flow cytometry. 

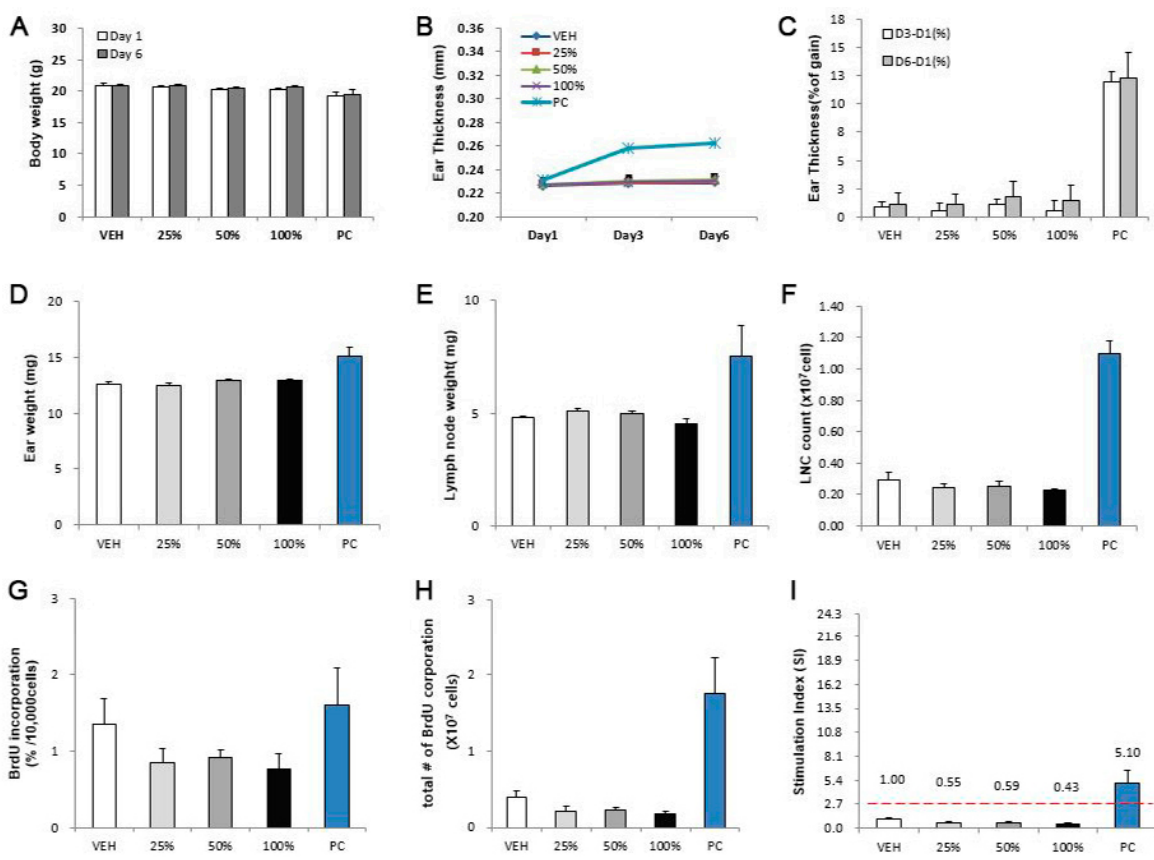

Figure 4. SWCNT skin sensitization test results in LLNA: BrdU-FCM assay. The evaluation parameters were as follows: (A) Body weight (g), (B) ear thickness (mm), (C) ear thickness (\% of gain), (D) ear weight (mg), (E) lymph node weight (mg), (F) lymph node cell (LNC) count $\left(\times 10^{7}\right.$ cells), (G) BrdU incorporation (\%/10,000 cells), (H) total number of BrdU corporation $\left(\times 10^{7}\right.$ cells), (I) stimulation index (SI). Data are expressed as mean \pm standard deviation values $(n=4)$.
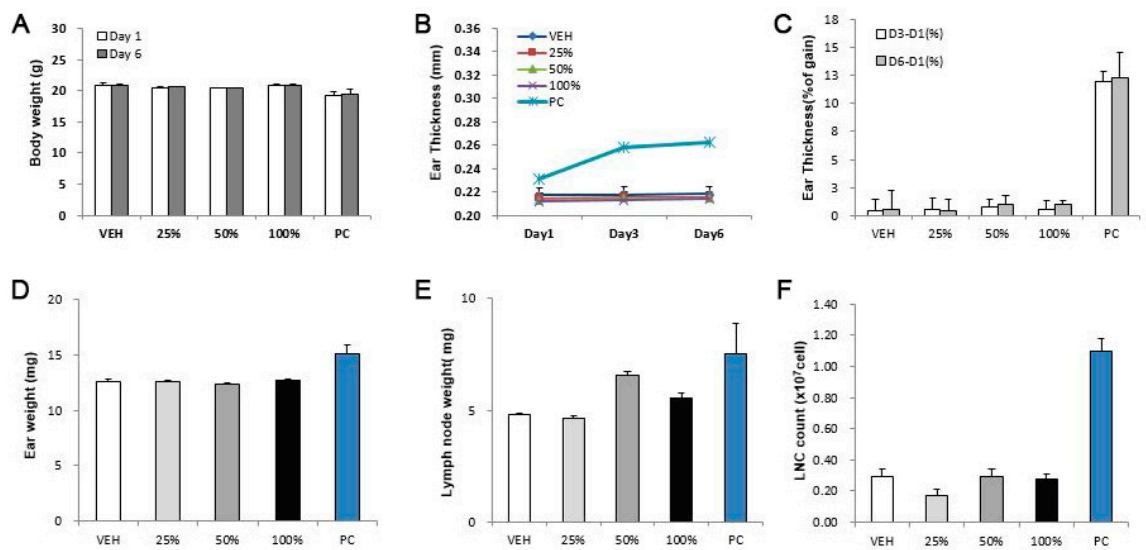

$\mathrm{F}$
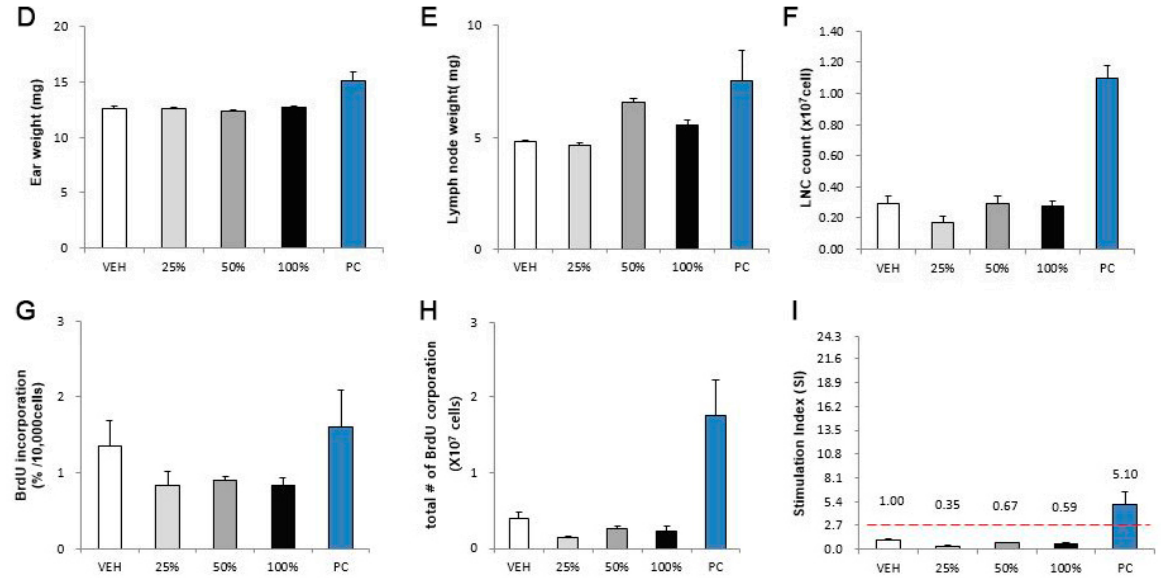

Figure 5. MWCNT skin sensitization test results in LLNA: BrdU-FCM assay. The evaluation parameters were as follows: (A) Body weight (g), (B) ear thickness (mm), (C) ear thickness (\% of gain), (D) ear weight (mg), (E) lymph node weight (mg), (F) LNC count $\left(\times 10^{7}\right.$ cells), (G) BrdU incorporation $(\% / 10,000$ cells), (H) total number of BrdU corporation $\left(\times 10^{7}\right.$ cells), (I) stimulation index (SI). Data are expressed as mean \pm standard deviation values $(n=4)$.

\section{Discussion}

With the growing emphasis of the 3R principles of reduction, replacement, and refinement of test animals, the use of test animals in toxicity studies in the recent international community has 
always been a major issue [13]. Animal alternative testing methods have been suggested by various countries and institutions, including the European Union Reference Laboratory for Alternatives to Animal Testing, Interagency Coordinating Committee on the Validation of Alternative Methods, and Japanese Center for the Validation of Alternative Methods. Various studies are being carried out on this subject, and the OECD has approved, enacted, and distributed guidelines for alternative test methods. The OECD TG 442 guidelines can be classified into four key events as follows: Key events 1 : Molecular initiation event; key events 2, 3: Cellular response; and key events 4: Organ response based on AOP inducing skin sensitization (Figure 6).

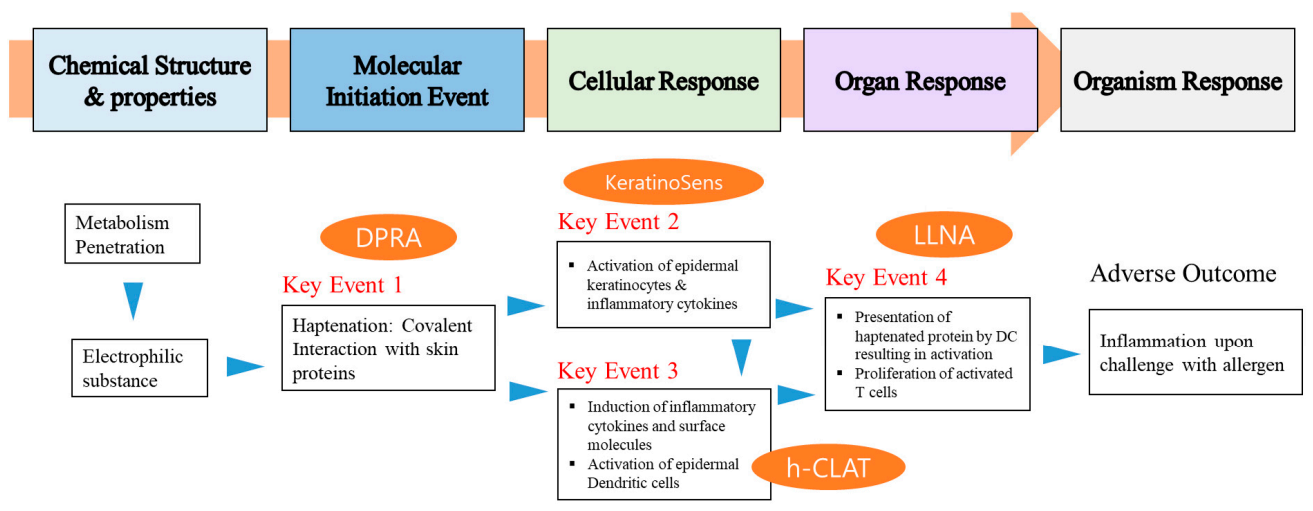

Figure 6. Overview of skin sensitization adverse outcome pathway (AOP).

The most basic step to induce skin sensitization depends on the 'immunogenicity' of the substance. Nanomaterials are of solid form but have a very small size compared to bulk materials. One dimension has a size of less than $100 \mathrm{~nm}$, and these substances have the potential to induce an immune response through "Haptenation" by binding to carrier proteins in the physiological environment. The CNT used in this study is a substance that is mentioned as an adjuvant candidate and has the potential to induce an immune response by binding to a carrier protein [26]. In addition, it has been reported that when exposed to the body, it penetrates into tissues and induces persistent inflammatory cytokines, as well as a tendency to attract inflammatory cells and lymphocytes to the inflammatory site [23]. Therefore, in order to evaluate the skin sensitization potential of CNTs, we evaluated, by adopting key events 2 and 4 , the method of confirming cellular response and organ response in skin sensitization AOP.

The accuracy of the KeratinoSens ${ }^{\mathrm{TM}}$ assay for identifying sensitizers was shown to be 77\% (155/201), with a sensitivity of $78 \%$ (71/91). In addition, laboratory-to-laboratory reproducibility has been reported to be approximately $85 \%[27,28]$. Although there are restrictions on testing for insoluble substances, some research cases have proven that these substances can be evaluated [29,30]. The LLNA: BrdU-FCM test method uses animals, and previously reported studies have suggested the possibility of evaluating nanomaterials. Park et al. conducted an LLNA test using titanium nanomaterials and reported that titanium did not induce sensitization [20].

The two types of CNTs used in our study are insoluble in most solvents and have the characteristic to easily form aggregates. As the major toxicity indicator of nanomaterials, proper dispersion is very important in predicting accurate toxicity, and hence, homogeneous dispersion in solvents is important. We used serum protein to improve the dispersion of CNTs in both tests [31]. In the in vitro test, dispersion was induced using the FBS component contained in the medium. In particular, the mouse serum, as a nanomaterial dispersant used in animal tests, not only induces improvement in large aggregation when inactivated serum obtained from the same species/line was used, but also proved that there were no side effects caused by the serum [32,33].

We report for the first time the sensitization results of CNTs using the KeratinoSens ${ }^{\mathrm{TM}}$ and LLNA: BrdU-FCM test methods in this study. In summary, the skin sensitization results for both SWCNTs and MWCNTs, using the two alternative tests, were negative. In our study, IC50 results were established for the KeratinoSens ${ }^{\mathrm{TM}}$ test for the first time, which was established based on the mass dose. 
Cytotoxicity by CNTs is primarily influenced by physical factors related to size such as aspect ratio and length. Asbestos-like forms of CNTs can cause incomplete phagocytosis and induce the formation of granulomas in the mouse pleura through persistent lymphocyte recruitment and cytokine induction in the chronic inflammatory stage [23]. In our study results, it was observed that SWCNTs induced a higher cytotoxicity than MWCNTs at the same concentration. SWCNTs with thinner diameters at smaller lengths appear to induce high cytotoxicity.

In addition, this study is the first alternative test case of SWCNTs evaluated using mice. Ema et al. performed the traditional skin sensitization test, guinea pig maximization test (GPMT), to evaluate CNTs, and reported SWCNTs and MWCNTs as the final nonsensitizing substance [34]. In addition, MWCNTs were evaluated as substances that do not induce sensitization in LLNA tests using mice $[35,36]$. There are currently a wide variety of types of carbon nanotubes, but in this study, two types of nanotubes were used only. In order to ensure the safety of commercialized CNTs, it will be necessary to accumulate data through more studies.

\section{Conclusions}

In this study, we report for the first time the sensitization results of CNTs using the KeratinoSens ${ }^{\mathrm{TM}}$ and LLNA: BrdU-FCM test methods in this study. This study found that both SWCNTs and MWCNTs do not induce skin sensitization for in vitro and in vivo levels. These results suggest that the ARE-Nrf2 Luciferase KeratinoSens ${ }^{\mathrm{TM}}$ and LLNA: BrdU-FCM assay may be useful as alternative assays for evaluating the potential of some nanomaterials that can induce skin sensitization. Further studies are needed evaluate the sensitization of nanomaterials more accurately. In addition, it is necessary to establish skin sensitization guidelines for specific nanomaterials based on various studies.

Author Contributions: Participated in the experimental design and data analysis: S.-H.K. and J.K.L.; conducted the experiments: S.-H.K., D.H.L., J.H.L., J.-Y.Y. and H.-S.S., with help of J.L. and K.J.; contributed to the writing of the manuscript: J.J. and J.-H.O. All authors have read and agreed to the published version of the manuscript.

Funding: This work was supported by a grant (18181MFDS361, and 20181MFDS401) from the Ministry of Food and Drug Safety, Korea.

Conflicts of Interest: The authors declare that they have no known competing financial interest or personal relationships that could have appeared to influence the work reported in this paper.

$\begin{array}{ll}\text { Abbreviations } \\ \text { AOP } & \text { Adverse outcome pathway } \\ \text { CNT } & \text { Carbon nanotube } \\ \text { DMF } & \text { N,N-Dimethylformamide } \\ \text { DMEM } & \text { Dulbecco's modified Eagle's medium } \\ \text { DPRA } & \text { Direct peptide reactivity assay } \\ \text { FBS } & \text { Fetal bovine serum } \\ \text { FCM } & \text { Flow cytometry } \\ \text { IACUC } & \text { Institutional Animal Care and Use Committee } \\ \text { LLNA } & \text { Local lymph node assay } \\ \text { LNC } & \text { Lymph node cells } \\ \text { MFDS } & \text { Ministry of Food and Drug Safety } \\ \text { MWCNTs } & \text { Multi-walled carbon nanotubes } \\ \text { SI } & \text { Stimulation index } \\ \text { OECD } & \text { Organization for Economic Cooperation and } \\ & \text { Development } \\ \text { SWCNTs } & \text { Single-wall carbon nanotubes } \\ \text { TEM } & \text { Transmission electron microscopy }\end{array}$




\section{References}

1. Bandaru, P.R. Electrical Properties and Applications of Carbon Nanotube Structures. J. Nanosci. Nanotechnol. 2007, 7, 1239-1267. [CrossRef]

2. Kostarelos, K.; Bianco, A.; Prato, M. Promises, facts and challenges for carbon nanotubes in imaging and therapeutics. Nat. Nanotechnol. 2009, 4, 627-633. [CrossRef] [PubMed]

3. ISO (International Organization for Standardization). Nanotechnologies-Terminology and Definitions for Nanoobjects-Nanoparticle, Nanofiber and Nanoplate; ISO: Geneva, Switzerland, 2008; ISO/TS 27687.

4. Oberdörster, G.; Maynard, A.D.; Donaldson, K.; Castranova, V.; Fitzpatrick, J.; Ausman, K.D.; Carter, J.M.; Karn, B.; Kreyling, W.; Lai, D.Y.; et al. Principles for characterizing the potential human health effects from exposure to nanomaterials: Elements of a screening strategy. Part. Fibre Toxicol. 2005, 2, 8. [CrossRef] [PubMed]

5. Donaldson, K.; Schinwald, A.; Murphy, F.; Cho, W.-S.; Duffin, R.; Tran, L.; Poland, C.A. The Biologically Effective Dose in Inhalation Nanotoxicology. Acc. Chem. Res. 2013, 46, 723-732. [CrossRef]

6. Braakhuis, H.M.; Park, M.V.D.Z.; Gosens, I.; De Jong, W.H.; Cassee, F.R. Physicochemical characteristics of nanomaterials that affect pulmonary inflammation. Part. Fibre Toxicol. 2014, 11, 18. [CrossRef] [PubMed]

7. Cho, W.-S.; Duffin, R.; Thielbeer, F.; Bradley, M.; Megson, I.L.; MacNee, W.; Poland, C.A.; Tran, C.L.; Donaldson, K. Zeta Potential and Solubility to Toxic Ions as Mechanisms of Lung Inflammation Caused by Metal/Metal Oxide Nanoparticles. Toxicol. Sci. 2012, 126, 469-477. [CrossRef]

8. Cho, W.-S.; Kang, B.-C.; Lee, J.K.; Jeong, J.; Che, J.-H.; Seok, S.H. Comparative absorption, distribution, and excretion of titanium dioxide and zinc oxide nanoparticles after repeated oral administration. Part. Fibre Toxicol. 2013, 10, 9. [CrossRef] [PubMed]

9. Jeong, J.; Kim, S.-H.; Lee, S.; Lee, D.-K.; Han, Y.; Jeon, S.; Cho, W.-S. Differential Contribution of Constituent Metal Ions to the Cytotoxic Effects of Fast-Dissolving Metal-Oxide Nanoparticles. Front. Pharmacol. 2018, 9, 15. [CrossRef] [PubMed]

10. Filon, F.L.; Mauro, M.; Adami, G.; Bovenzi, M.; Crosera, M. Nanoparticles skin absorption: New aspects for a safety profile evaluation. Regul. Toxicol. Pharmacol. 2015, 72,310-322. [CrossRef]

11. Journeay, W.S.; Goldman, R. Occupational handling of nickel nanoparticles: A case report. Am. J. Ind. Med. 2014, 57, 1073-1076. [CrossRef] [PubMed]

12. Yapar, E.A.; İnal, Ö.; Yapar, E.A.; Yapar, Ö.İ.E.A.; Inal, Ö. Nanomaterials and cosmetics. İstanbul Üniversitesi Eczacilık Fakültesi Derg. 2012, 42, 43-70.

13. Rusche, B. The 3Rs and animal welfare-conflict or the way forward? Altex 2003, 20, 63-76. [PubMed]

14. Kaluzhny, Y.; Kandárová, H.; Hayden, P.; Kubilus, J.; D’Argembeau-Thornton, L.; Klausner, M. Development of the EpiOcular ${ }^{\mathrm{TM}}$ Eye Irritation Test for Hazard Identification and Labelling of Eye Irritating Chemicals in Response to the Requirements of the EU Cosmetics Directive and REACH Legislation. Altern. Lab. Anim. 2011, 39, 339-364. [CrossRef] [PubMed]

15. OECD. The Adverse Outcome Pathway for Skin Sensitisation Initiated by Covalent Binding to Proteins, OECD Series on Testing and Assessment, No. 168; OECD Publishing: Paris, France, 2014. [CrossRef]

16. OECD. Test No. 442C: In Chemico Skin Sensitisation: Assays Addressing the Adverse Outcome Pathway Key Event on Covalent Binding to Proteins. Available online: https:/www.oecd-ilibrary.org/environment/ test-no-442c-in-chemico-skin-sensitisation_9789264229709-en (accessed on 26 June 2020).

17. OECD. Test No. 442D: In Vitro Skin Sensitisation: Are-Nrf2 Luciferase Test Method, OECD Guidelines for the Testing of Chemicals. Available online: https://www.oecd-ilibrary.org/environment/test-no-442d-invitro-skin-sensitisation_9789264229822-en (accessed on 25 June 2018).

18. OECD. Test No. 442E: In Vitro Skin Sensitisation: In Vitro Skin Sensitisation Assays Addressing the Key Event on Activation of Dendritic Cells on the Adverse Outcome Pathway for Skin Sensitisation. Available online: https://www.oecd-ilibrary.org/environment/test-no-442e-in-vitro-skin-sensitisation_ 9789264264359-en (accessed on 25 June 2018).

19. OECD. Test No. 442B: Skin Sensitization: Local Lymph Node Assay: BrdU-Elisa or -Fcm, Oecd Guidelines for the Testing of Chemicals. Available online: https:/www.oecd-ilibrary.org/environment/test-no-442bskin-sensitization_9789264090996-en (accessed on 25 June 2018).

20. Park, Y.-H.; Jeong, S.H.; Yi, S.M.; Choi, B.H.; Kim, Y.-R.; Kim, I.-K.; Kim, M.-K.; Son, S.W. Analysis for the potential of polystyrene and $\mathrm{TiO} 2$ nanoparticles to induce skin irritation, phototoxicity, and sensitization. Toxicol. Vitr. 2011, 25, 1863-1869. [CrossRef] [PubMed] 
21. Yoshioka, Y.; Kuroda, E.; Hirai, T.; Tsutsumi, Y.; Ishii, K.J. Allergic Responses Induced by the Immunomodulatory Effects of Nanomaterials upon Skin Exposure. Front. Immunol. 2017, 8, 169. [CrossRef]

22. Kim, S.H.; Lee, D.H.; Lee, J.H.; Yang, J.Y.; Seok, J.H.; Jung, K.; Lee, J.K. Evaluation of the skin sensitization potential of metal oxide nanoparticles using the ARE-Nrf2 Luciferase KeratinoSens ${ }^{\mathrm{TM}}$ assay. Toxicol. Res. 2020, unpublished.

23. Lee, D.-K.; Jeon, S.; Han, Y.; Kim, S.-H.; Lee, S.; Yu, I.J.; Song, K.S.; Kang, A.; Yun, W.S.; Kang, S.-M.; et al. Threshold Rigidity Values for the Asbestos-like Pathogenicity of High-Aspect-Ratio Carbon Nanotubes in a Mouse Pleural Inflammation Model. ACS Nano 2018, 12, 10867-10879. [CrossRef]

24. Jung, K.-M.; Bae, I.; Kim, B.-H.; Kim, W.-K.; Chung, J.-H.; Park, Y.-H.; Lim, K.-M. Comparison of flow cytometry and immunohistochemistry in non-radioisotopic murine lymph node assay using bromodeoxyuridine. Toxicol. Lett. 2010, 192, 229-237. [CrossRef]

25. Ahn, I.; Kim, T.-S.; Jung, E.-S.; Yi, J.-S.; Jang, W.-H.; Jung, K.-M.; Park, M.; Jung, M.-S.; Jeon, E.-Y.; Yeo, K.-U.; et al. Performance standard-based validation study for local lymph node assay: 5-bromo-2-deoxyuridine-flow cytometry method. Regul. Toxicol. Pharmacol. 2016, 80, 183-194. [CrossRef]

26. Parra, J.; Abad-Somovilla, A.; Mercader, J.V.; Taton, T.A.; Abad-Fuentes, A. Carbon nanotube-protein carriers enhance size-dependent self-adjuvant antibody response to haptens. J. Control. Release 2013, 170, $242-251$. [CrossRef]

27. Natsch, A.; Ryan, C.A.; Foertsch, L.; Emter, R.; Jaworska, J.; Gerberick, F.; Kern, P. A dataset on 145 chemicals tested in alternative assays for skin sensitization undergoing prevalidation. J. Appl. Toxicol. 2013, 33, 1337-1352. [CrossRef]

28. EURL-ECVAM. Recommendation on the KeratinoSens ${ }^{\mathrm{TM}}$ Assay for Skin Sensitisation Testing. 2014. Available online: https://ec.europa.eu/jrc/en/publication/eur-scientific-and-technical-research-reports/eurlecvam-recommendation-keratinosenstm-assay-skin-sensitisation-testing (accessed on 22 October 2020).

29. Andres, E.; Sá-Rocha, V.M.; Barrichello, C.; Haupt, T.; Ellis, G.; Natsch, A. The sensitivity of the KeratinoSens ${ }^{\mathrm{TM}}$ assay to evaluate plant extracts: A pilot study. Toxicol. Vitro 2013, 27, 1220-1225. [CrossRef] [PubMed]

30. Settivari, R.S.; Gehen, S.C.; Amado, R.A.; Visconti, N.R.; Boverhof, D.R.; Carney, E.W. Application of the KeratinoSens ${ }^{\mathrm{TM}}$ assay for assessing the skin sensitization potential of agrochemical active ingredients and formulations. Regul. Toxicol. Pharmacol. 2015, 72, 350-360. [CrossRef] [PubMed]

31. Bihari, P.; Vippola, M.; Schultes, S.; Praetner, M.; Khandoga, A.G.; Reichel, C.A.; Coester, C.; Tuomi, T.; Rehberg, M.; Krombach, F. Optimized dispersion of nanoparticles for biological in vitro and in vivo studies. Part. Fibre Toxicol. 2008, 5, 14. [CrossRef] [PubMed]

32. Cho, W.-S.; Thielbeer, F.; Duffin, R.; Johansson, E.M.V.; Megson, I.L.; MacNee, W.; Bradley, M.; Donaldson, K. Surface functionalization affects the zeta potential, coronal stability and membranolytic activity of polymeric nanoparticles. Nanotoxicology 2013, 8, 202-211. [CrossRef] [PubMed]

33. Lee, S.; Hwang, S.-H.; Jeong, J.; Han, Y.; Kim, S.-H.; Lee, D.-K.; Lee, H.-S.; Chung, S.-T.; Jeong, J.; Roh, C.; et al. Nickel oxide nanoparticles can recruit eosinophils in the lungs of rats by the direct release of intracellular eotaxin. Part. Fibre Toxicol. 2016, 13, 30. [CrossRef] [PubMed]

34. Ema, M.; Matsuda, A.; Kobayashi, N.; Naya, M.; Nakanishi, J. Evaluation of dermal and eye irritation and skin sensitization due to carbon nanotubes. Regul. Toxicol. Pharmacol. 2011, 61, 276-281. [CrossRef]

35. OECD. Single Walled Carbon Nanotubes (SWCNTs): Summary of the Dossier, Series on the Safety of Manufactured Nanomaterials No. 70. Available online: http://www.oecd.org/officialdocuments/ publicdisplaydocumentpdf/?cote=env/jm/mono(2016)22\&doclanguage=en (accessed on 7 July 2016).

36. OECD. Multi Walled Carbon Nanotubes (MWCNT): Summary of the Dossier, Series on the Safety of Manufactured Nanomaterials No. 68. Available online: http://www.oecd.org/officialdocuments/ publicdisplaydocumentpdf/?cote=env/jm/mono(2016)20\&doclanguage=en (accessed on 30 May 2016).

Publisher's Note: MDPI stays neutral with regard to jurisdictional claims in published maps and institutional affiliations. 